\title{
Ice-algal carbon supports harp and ringed seal diets in the European Arctic: evidence from fatty acid and stable isotope markers
}

\author{
E. H. Kunisch ${ }^{1, *}$, M. Graeve ${ }^{2}$, R. Gradinger ${ }^{1}$, T. Haug ${ }^{3}$, K. M. Kovacs ${ }^{4}$, C. Lydersen ${ }^{4}$, \\ Ø. Varpe $^{5,6}$, B. A. Bluhm ${ }^{1}$ \\ ${ }^{1}$ Department of Arctic and Marine Biology, UiT The Arctic University of Norway, 9037 Tromsø, Norway \\ ${ }^{2}$ Ecological Chemistry, Alfred Wegener Institute Helmholtz Center for Polar and Marine Research, 27570 Bremerhaven, Germany \\ ${ }^{3}$ Institute of Marine Research, Fram Centre, 9296 Tromsø, Norway \\ ${ }^{4}$ Norwegian Polar Institute, Fram Centre, 9296 Tromsø, Norway \\ ${ }^{5}$ Department of Biological Sciences, University of Bergen, 5020 Bergen, Norway \\ ${ }^{6}$ Norwegian Institute for Nature Research, 5006 Bergen, Norway
}

\begin{abstract}
Sea-ice declines in the European Arctic have led to substantial changes in marine food webs. To better understand the biological implications of these changes, we quantified the contributions of ice-associated and pelagic carbon sources to the diets of Arctic harp and ringed seals using compound-specific stable isotope ratios of fatty acids in specific primary producer biomarkers derived from sea-ice algae and phytoplankton. Comparison of fatty acid patterns between these 2 seal species indicated clear dietary separation, while the compound-specific stable isotope ratios of the same fatty acids showed partial overlap. These findings suggest that harp and ringed seals target different prey sources, yet their prey rely on ice and pelagic primary production in similar ways. From Bayesian stable isotope mixing models, we estimated that relative contributions of sympagic and pelagic carbon in seal blubber was an average of $69 \%$ and $31 \%$ for harp seals, and $72 \%$ and $28 \%$ for ringed seals, respectively. The similarity in the Bayesian estimations also indicates overlapping carbon sourcing by these 2 species. Our findings demonstrate that the seasonal ice-associated carbon pathway contributes substantially to the diets of both harp and ringed seals.
\end{abstract}

KEY WORDS: Carbon source $\cdot$ Climate change $\cdot$ Food webs $\cdot$ Compound-specific stable isotopes · Foraging $\cdot$ Pinnipeds $\cdot$ Sea-ice algae $\cdot$ Phytoplankton

\section{INTRODUCTION}

Niche partitioning theory states that species coexisting in the same foraging space are expected to have different diets or resource use, effectively limiting competition (MacArthur 1958). In the European Arctic, harp (Pagophilus groenlandicus) and ringed (Pusa hispida) seals are found in similar habitats for at least part of the year, along the sea-ice edge and in coastal Svalbard waters during spring and summer (Hamilton et al. 2021). They often target similar ice-

${ }^{*}$ Corresponding author: erin.kunisch@uit.no associated prey (Nilssen et al. 1995b, Labansen et al. 2007, Lindstrøm et al. 2013), but exhibit some niche separation via differences in foraging behavior (dive depth, size of prey selected; Wathne et al. 2000). Trophic niche partitioning can be characterized by dietary composition but also by which carbon end members (i.e. autotrophic primary producers) support their prey sources, and both aspects are studied here. In the Arctic specifically, some of the organic carbon of their prey can be traced back to sea-ice primary production (Kohlbach et al. 2017), an early-

() The authors 2021. Open Access under Creative Commons by Attribution Licence. Use, distribution and reproduction are unrestricted. Authors and original publication must be credited. 
season energy source that fuels food webs within the Arctic (Ji et al. 2013). Arctic sea-ice declines have already resulted in breeding and foraging habitat reductions for harp and ringed seals (Hamilton et al. 2017, 2019, Stenson et al. 2020). These pinnipeds will likely encounter increased competition in the remaining sea-ice areas from boreal species shifting northward (Kovacs et al. 2011, Øigård et al. 2013) and from each other, given that they are increasingly overlapping in some areas of their Barents Sea distributions (Bengtsson et al. 2020). The overall reduction or loss of sea-ice primary production and its cumulative effects on food webs are currently unknown, though harp seals are showing declining body condition that is thought to be due to competition with other predators, including the large standing stock of Atlantic cod Gadus morhua, which has shifted northward in the Barents Sea region (Stenson et al. 2020).

Harp and ringed seals are 2 ice-associated seals, but the nature of their dependence on sea ice differs. Both species are monitored in the study region and are harvested for subsistence (harp seals, Greenland) or commercially (ringed seals, Svalbard). Harp seals are a North Atlantic drift-ice breeding species that migrates into the High Arctic for summer feeding (Stenson et al. 2020). They associate with sea ice most of the year but can spend time in open-water areas outside the moulting and breeding seasons; therefore, their diets are particularly variable by season and region (e.g. Nilssen et al. 1995a,b, Lawson \& Hobson 2000, Stenson et al. 2020). Harp seals from the Greenland and White Seas perform seasonal migrations from southerly breeding areas, where they use drift or land-fast ice, northward to the seaice edge north of Svalbard for summer and autumn foraging (Haug et al. 1994, Folkow et al. 2004). These foraging migrations are important for regaining energy stores used during the breeding and moulting seasons in the spring (Nilssen et al. 1997).

Ringed seals are a circumpolar Arctic species that is highly reliant on sea ice throughout the year (Laidre et al. 2008). Their diet is also known to vary regionally and seasonally (Holst et al. 2001, Thiemann et al. 2007, Bengtsson et al. 2020). In Svalbard, ringed seal movement and diving patterns suggest that adult animals forage primarily at tidewater glacier fronts (Hamilton et al. 2016, 2019) and trends in the recent decade show that they are retracting into these Arctic refugial areas as sea-ice declines continue (Hamilton et al. 2019). Young ringed seals do not stay coastal in summer; they migrate north to the sea-ice edge to forage (Freitas et al. 2008, Hamilton et al. 2015). Despite having to travel longer to reach the sea ice in recent years, they are still undertaking these foraging migrations (Hamilton et al. 2015).

For many Arctic organisms, sympagic (ice-associated) primary production is an essential early-season energy source (McMahon et al. 2006, Søreide et al. 2010, Ji et al. 2013). This production supports prey of higher trophic levels such as seabirds and walrus Odobenus rosmarus rosmarus (Cusset et al. 2019, Yurkowski et al. 2020). In the Eurasian Basin, which is partially covered by sea ice year-round, sympagic carbon contributed as much as $92 \%$ to the diets of various underice and pelagic zooplankton and between 34 and $65 \%$ for various tissues of polar cod Boreogadus saida (Kohlbach et al. 2016, 2017). In the seasonally icecovered Bering Sea, sympagic primary production has also been shown to make high contributions to the diets of ice-associated seals, with estimates ranging from 62 to $80 \%$ for bearded seals Erignathus barbatus, 21 to $60 \%$ for ringed seals, and 51 to $62 \%$ for spotted seals Phoca largha (Wang et al. 2016). It is unknown whether Arctic seal diets in the European Arctic also have similarly high contributions of seaice algal-sourced carbon, as pelagic primary production would be expected to be more important in the seasonal ice-covered zones.

Organic carbon in sea-ice-covered ecosystems originates primarily from ice algae and phytoplankton. These primary producers often have distinct carbon isotope signatures $\left(\delta^{13} \mathrm{C}\right)$, largely due to the fact that sea-ice algae compete for light and space in a closed carbon-limiting system that has minimal exchange with the underlying water column (Horner \& Schrader 1982, Fry \& Sherr 1984, Kennedy et al. 2002). As a result, bulk $\delta^{13} \mathrm{C}$ values of ice algae are often higher when compared to phytoplankton values (Gradinger 2009, de la Vega et al. 2019), though these values can overlap with one another depending on ice algal biomass and the time of year when sampling takes place (Søreide et al. 2006, Tremblay et al. 2006, Gradinger 2009). Bulk stable isotope analysis of carbon is most widely used (de la Vega et al. 2019), but delivers a single value encompassing a mixture of all organic compounds. In contrast, compound-specific stable isotope analysis provides more detailed information on the sources of individual compounds, such as fatty acids, which in themselves can be used as tracers in food web studies (Middelburg 2014, Burian et al. 2020).

Complementary to isotopic research, the trophic biomarker approach is a selective process involving certain marker fatty acids that can be used to determine consumer diets and energy flow within food webs (Lee et al. 1971, Sargent \& Whittle 1981, Falk- 
Petersen et al. 1990). Two of the most abundant fatty acids in Bacillariophyceae, or diatoms, are 16:1(n-7) and 20:5(n-3) (Viso \& Marty 1993, Reitan et al. 1994, Jónasdóttir 2019). Sea ice in general and specifically first-year sea-ice algal communities are often dominated by diatoms (Leu et al. 2006, Søreide et al. 2006, Fernández-Méndez et al. 2018), which contribute the highest algal fraction to sea-ice particulate organic matter (Van Leeuwe et al. 2018). Dinoflagellates (Dinophyceae) also have characteristic marker fatty acids, namely, higher amounts of 18:4(n-3) and 22:6(n-3) (Viso \& Marty 1993, Graeve et al. 1994). These fatty acids are characteristic for diatoms or dinoflagellates occurring in sea ice and/or water (Søreide et al. 2008), but again these specific fatty acids in particulate organic matter inside sea ice can have higher $\delta^{13} \mathrm{C}$ values (Wang et al. 2014). Thus, combining marker fatty acids with their individual stable isotope values, or $\delta^{13} \mathrm{C}_{\mathrm{FA}}$, may provide further differentiation between carbon sources and their assimilation pathways throughout food webs (Budge et al. 2008).

The overarching objective in this study was to identify potential trophic niche differences between harp and ringed seals from 2 angles: firstly, by identifying potential differences in dietary items (fatty acid analysis), and secondly, by identifying potential differences in carbon sourcing from phytoplankton and ice algae (isotopic ratio analysis). To address these 2 aspects, we used fatty acids and $\delta^{13} C_{\mathrm{FA}}$ to (1) determine any differences in sea-ice algae and phytoplankton values, (2) evaluate potential dietary fatty acid compositional differences between harp and ringed seals, and (3) estimate the relative contribution of sympagic and pelagic primary production to harp and ringed seal diets using the $\delta^{13} \mathrm{C}_{\mathrm{FA}}$ values of 4 trophic biomarker fatty acids. Based on previous studies documenting differences in $\delta^{13} \mathrm{C}_{\mathrm{FA}}$ values in ice algae and phytoplankton (Budge et al. 2008, Wang et al. 2014), we first predicted that even if the fatty acid compositions of the 2 primary production sources were similar, sympagic algae would have $\delta^{13} \mathrm{C}_{\mathrm{FA}}$ values higher than pelagic values. Second, we hypothesized that fatty acid profiles would be similar between the 2 seal species given their dietary overlap. Third, we hypothesized that sympagic carbon is more likely to contribute to the diet of ringed seals because of their stronger association with sea ice.

\section{MATERIALS AND METHODS}

To address our first hypothesis, we examined the fatty acid compositions and specific $\delta^{13} \mathrm{C}_{\mathrm{FA}}$ values of sea-ice algae and phytoplankton in summer and determined if there were differences between the 2 sources of primary production. To address hypothesis 2 , we tested if harp and ringed seals differed in their blubber fatty acid compositions and the $\delta^{13} \mathrm{C}_{\mathrm{FA}}$ values of the trophic biomarker fatty acids. Finally, to address hypothesis 3 , differences in the $\delta^{13} \mathrm{C}_{\mathrm{FA}}$ values between sympagic and pelagic sources were used to quantify the contribution of these different carbon sources to the harp and ringed seal diets.

\subsection{Study area and sample collection}

Sea-ice algae and phytoplankton were collected north of Svalbard, over the Yermak Plateau, in the northern Barents Sea and in the Nansen Basin (Fig. 1). Sample collection of particulate organic matter from sea-ice algae and phytoplankton occurred during 2 consecutive cruises onboard the RV 'Polarstern' (Fig. 1). From 3 to 15 June 2017, the RV 'Polarstern' was anchored to an ice floe north of Svalbard. During this time, the ice floe drifted approximately $100 \mathrm{~km}$, circling above the Yermak Plateau (Fig. 1). From 25 June to 14 July, the RV 'Polarstern' traveled north through the Barents Sea and into the deep Nansen Basin. Sample collection occurred at various stations throughout this area (Table 1). In-ice chlorophyll a ranged from 0.11 to $0.39 \mathrm{mg} \mathrm{m}^{-2}$ (Castellani et al. 2020), and all sea ice encountered during both cruises was first-year ice.

Particulate organic matter within sea ice (iPOM) was collected by taking ice cores with a $9 \mathrm{~cm}$ inner diameter ice corer (Kovacs Enterprises). The bottom $5 \mathrm{~cm}$ of each ice core was cut off and melted onboard the ship in a $4^{\circ} \mathrm{C}$ dark room. To obtain more material, ice-algae aggregates floating in auger holes were opportunistically collected by hand and placed into $50 \mathrm{ml}$ Falcon tubes (Fisher Scientific). During 3-15 June, iPOM was collected from 7 ice cores and 4 floating ice-algae aggregates. During 25 June-14 July, iPOM was collected from 17 ice cores taken at 5 ice stations and 6 hand-collected ice-algae aggregates were collected at 3 ice stations. Particulate organic matter from the phytoplankton community (pPOM) was also collected during both cruises. During 3-15 June, only one pPOM water sample (at $30 \mathrm{~m}$ ) ended up being usable and was taken by hand through a hole in the sea ice using a Kemmerer water sampler (Eijkelkamp). During 25 June-14 July, pPOM was collected at 12 different stations using a CTD rosette water sampler (Seabird SBE9+) at the chlorophyll maximum layer (between 6 and $40 \mathrm{~m}$ ). All samples 


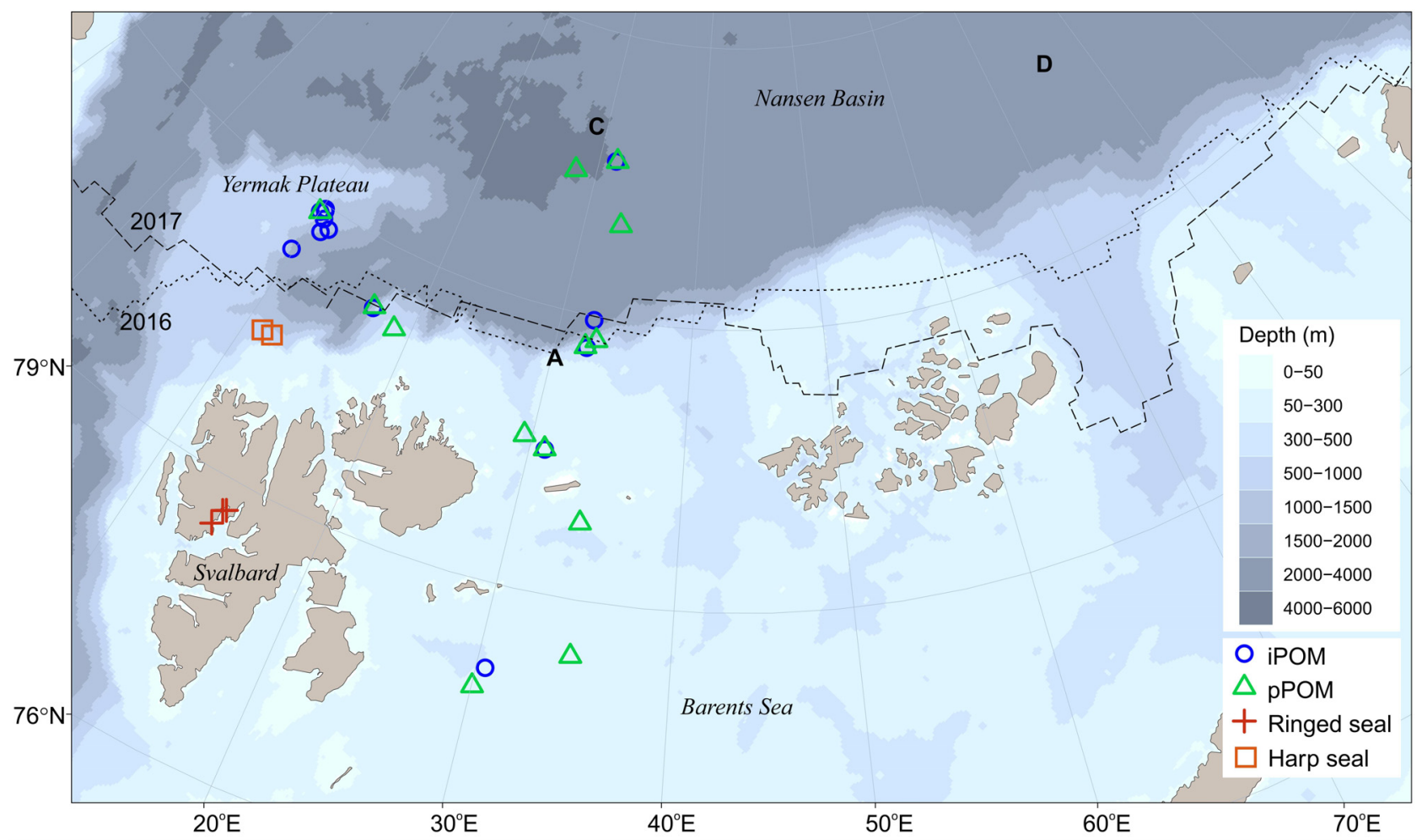

Fig. 1. Map of the study area. Black lines show minimum September sea-ice extent in 2016 (dotted line) and 2017 (dashed line; data: National Snow and Ice Data Center, Fetterer et al. [2017]). A, C, and D refer to pPOM stations included from Kohlbach et al. (2017). The study area map was generated with the ggOceanMaps package (Vihtakari 2020)

were filtered onto $0.7 \mu \mathrm{m}$ pre-combusted GF/F filters (Whatman, Merck). Filtered samples were subsequently wrapped in aluminum foil and stored in a $-80^{\circ} \mathrm{C}$ freezer until analysis.

Harp seals $(n=25)$ were shot for scientific purposes on ice floes north of Svalbard $\left(80.52^{\circ}-80.55^{\circ} \mathrm{N}\right.$, $11.4^{\circ}-11.8^{\circ} \mathrm{E}$ ), and samples were collected on 11 September 2016 (Fig. 1). Ringed seals were shot $(n=20)$ during an annual sport hunt that occurs in Svalbard each summer and autumn. Ringed seal samples were collected in Eckmanfjorden (78.49-78.66 ${ }^{\circ} \mathrm{N}, 14.40-$ $\left.14.58^{\circ} \mathrm{E}\right)$, Svalbard, between 26 June and $21 \mathrm{Sep}-$ tember 2017 (Fig. 1). Seal age was determined by counting cementum layers of sectioned teeth (mostly canines) (Scheffer 1950). For both species, ages $<1 \mathrm{yr}$ were considered young of the year, ages $1-5 \mathrm{yr}$ as juveniles, and seals $\geq 6$ yr as adults (Lydersen \& Gjertz 1987). Full-depth (from skin to muscle) blubber samples were taken from the trunk of the seal bodies immediately after collection, wrapped in aluminum foil and frozen at $-20^{\circ} \mathrm{C}$ until arrival at the laboratory, where they were subsequently stored at $-80^{\circ} \mathrm{C}$ until analysis. Blubber tissue fatty acids reflect signatures of acquired prey items consumed over time periods from weeks to months in seals (Nordstrom et al. 2008, Tollit et al. 2010). While different sections of blubber can reflect different time periods of when prey was acquired (Strandberg et al. 2008), we were interested in the cumulative incorporation of diet and carbon sources, and hence homogenized the whole blubber column.

\subsection{Fatty acid analysis}

All laboratory analyses were conducted at the Alfred Wegener Institute in Bremerhaven, Germany. Prior to lipid extraction, POM samples were removed from $-80^{\circ} \mathrm{C}$ freezers and freeze-dried for $24 \mathrm{~h}$. Seal blubber was first thawed in a refrigerator, and a longitudinal slice (from skin to muscle) was cut using a clean scalpel on a glass plate. The skin and any attached muscle tissue were cut away, and one blubber sample was analyzed per individual. Blubber samples were placed on individual pieces of aluminum foil and freeze-dried for $24 \mathrm{~h}$ (Rudy et al. 2016) leaving 2-9 g (dry mass) of blubber per individual.

Samples were mechanically homogenized, and lipids were extracted using dichloromethane/methanol 2:1 v/v (Folch et al. 1957). Total lipid mass of each sample was determined gravimetrically. Lipids were 
Table 1. Sample information for particulate organic matter from sea ice (iPOM) and phytoplankton (pPOM) collected from the Yermak Plateau (PS106.1), Barents Sea (PS106.2), and Nansen Basin (PS106.2), and for harp and ringed seals. Samples were analyzed for fatty acids (FA) and carbon isotope values of fatty acids $\left(\delta^{13} C_{F A}\right)$. Sea-ice coverage was acquired from the Copernicus Marine Service (https://marine.copernicus.eu/), which provides daily ice cover by $10 \mathrm{~km}^{2}$ for pack ice (POM and harp seal locations) and $1 \mathrm{~km}^{2}$ for land-fast ice (ringed seal locations)

\begin{tabular}{|c|c|c|c|c|c|c|c|c|}
\hline Group & $\begin{array}{l}\text { Sample } \\
\text { type }\end{array}$ & Data & $\mathrm{N}$ & Date & $\begin{array}{l}\text { Latitude } \\
\left({ }^{\circ} \mathrm{N}\right)\end{array}$ & $\begin{array}{l}\text { Longitude } \\
\left({ }^{\circ} \mathrm{E}\right)\end{array}$ & Station & $\begin{array}{c}\text { Sea-ice } \\
\text { coverage }(\%\end{array}$ \\
\hline \multirow[t]{8}{*}{ POM, PS106.1 } & iPOM & $\delta^{13} \mathrm{C}_{\mathrm{FA}}, \mathrm{FA}$ & 1 & 2 June 2017 & 81.411 & 9.786 & 19 & 91 \\
\hline & iPOM & $\delta^{13} C_{F A}, F A$ & 1 & 4 June 2017 & 81.964 & 10.243 & 21 & 96 \\
\hline & iPOM & $\delta^{13} C_{F A}, F A$ & 2 & 7 June 2017 & 81.942 & 10.308 & 24 & 95 \\
\hline & iPOM & $\delta^{13} \mathrm{C}_{\mathrm{FA}}, \mathrm{FA}$ & 2 & 9 June 2017 & 81.909 & 10.006 & 26 & 93 \\
\hline & pPOM & FA only & 1 & 9 June 2017 & 81.909 & 10.006 & & 93 \\
\hline & iPOM & FA only & 2 & 11 June 2017 & 81.867 & 10.557 & 28 & 99 \\
\hline & iPOM & $\delta^{13} \mathrm{C}_{\mathrm{FA}}, \mathrm{FA}$ & 2 & 14 June 2017 & 81.798 & 11.285 & 31 & 100 \\
\hline & iPOM & $\delta^{13} C_{F A}, F A$ & 1 & 15 June 2017 & 81.731 & 10.858 & 32 & 100 \\
\hline \multirow[t]{18}{*}{ POM, PS106.2 } & pPOM & $\delta^{13} \mathrm{C}_{\mathrm{FA}}, \mathrm{FA}$ & 1 & 25 June 2017 & 77.894 & 30.045 & 44 & 61 \\
\hline & iPOM & $\delta^{13} C_{F A}, F A$ & 7 & 25 June 2017 & 78.111 & 30.479 & 45 & 63 \\
\hline & pPOM & $\delta^{13} \mathrm{C}_{\mathrm{FA}}, \mathrm{FA}$ & 1 & 26 June 2017 & 78.405 & 34.703 & 47 & 28 \\
\hline & pPOM & $\delta^{13} \mathrm{C}_{\mathrm{FA}}, \mathrm{FA}$ & 1 & 27 June 2017 & 79.815 & 34.018 & 48 & 70 \\
\hline & pPOM & $\delta^{13} \mathrm{C}_{\mathrm{FA}}, \mathrm{FA}$ & 1 & 28 June 2017 & 80.515 & 30.972 & 50 & 94 \\
\hline & iPOM & FA only & 2 & 29 June 2017 & 80.508 & 30.984 & & 86 \\
\hline & pPOM & FA only & 1 & 30 June 2017 & 81.750 & 32.938 & 57 & 95 \\
\hline & iPOM & $\delta^{13} \mathrm{C}_{\mathrm{FA}}, \mathrm{FA}$ & 7 & 2 July 2017 & 81.655 & 32.342 & 66 & 98 \\
\hline & pPOM & FA only & 1 & 2 July 2017 & 81.664 & 32.237 & & 98 \\
\hline & iPOM & $\delta^{13} \mathrm{C}_{\mathrm{FA}}, \mathrm{FA}$ & 2 & 3 July 2017 & 81.958 & 32.482 & 67 & 95 \\
\hline & pPOM & FA only & 1 & 5 July 2017 & 83.000 & 33.162 & 69 & 90 \\
\hline & iPOM & $\delta^{13} \mathrm{C}_{\mathrm{FA}}, \mathrm{FA}$ & 3 & 6 July 2017 & 83.661 & 31.581 & 73 & 91 \\
\hline & pPOM & $\delta^{13} \mathrm{C}_{\mathrm{FA}}, \mathrm{FA}$ & 1 & 7 July 2017 & 83.664 & 31.721 & & 92 \\
\hline & pPOM & FA only & 1 & 8 July 2017 & 83.473 & 28.055 & 74 & 83 \\
\hline & iPOM & $\delta^{13} \mathrm{C}_{\mathrm{FA}}, \mathrm{FA}$ & 2 & 12 July 2017 & 81.308 & 16.886 & 80 & 78 \\
\hline & pPOM & $\delta^{13} \mathrm{C}_{\mathrm{FA}}, \mathrm{FA}$ & 1 & 12 July 2017 & 81.326 & 16.928 & & 78 \\
\hline & pPOM & $\delta^{13} C_{F A}, F A$ & 1 & 13 July 2017 & 81.205 & 18.835 & 83 & 89 \\
\hline & pPOM & FA only & 1 & 14 July 2017 & 80.611 & 29.489 & 85 & 73 \\
\hline Harp & & $\delta^{13} \mathrm{C}_{\mathrm{FA}}, \mathrm{FA}$ & 25 & 11 Sep 2016 & 80.517 & 11.400 & & 4 \\
\hline \multirow[t]{5}{*}{ Ringed } & & $\delta^{13} \mathrm{C}_{\mathrm{FA}}, \mathrm{FA}$ & 3 & 26 June 2017 & 78.491 & 14.400 & & 20 \\
\hline & & $\delta^{13} \mathrm{C}_{\mathrm{FA}}, \mathrm{FA}$ & 6 & 29 Aug 2017 & 78.491 & 14.400 & & 20 \\
\hline & & $\delta^{13} C_{F A}, F A$ & 2 & 9 Sep 2017 & 78.491 & 14.400 & & 50 \\
\hline & & $\delta^{13} \mathrm{C}_{\mathrm{FA}}, \mathrm{FA}$ & 3 & 17 Sep 2017 & 78.664 & 14.582 & & 5 \\
\hline & & $\delta^{13} \mathrm{C}_{\mathrm{FA}}, \mathrm{FA}$ & 6 & 21 Sep 2017 & 78.684 & 14.754 & & 0 \\
\hline
\end{tabular}

then converted into fatty acid methyl esters by using a solution of $3 \%$ concentrated sulfuric acid in methanol and heating for $4 \mathrm{~h}$ at $80^{\circ} \mathrm{C}$ (Kattner \& Fricke 1986). Subsequently, fatty acid methyl esters were quantified using an Agilent 6890N gas chromatograph (Agilent Technologies) with a DB-FFAP capillary column $(60 \mathrm{~m}$, $0.25 \mathrm{~mm}$ i.d., $0.25 \mu \mathrm{m}$ film thickness) supplied with a splitless injector and a flame ionization detector using temperature programming. Helium was used as the carrier gas. Fatty acid methyl esters were quantified with an internal standard, tricosanoic acid methyl ester (23:0) (Supelco), that was added prior to lipid extraction. The detection limit based on the certified reference material (Supelco 37 Component fatty acid methyl ester mix) was 10-20 ng per component. Clarity chromatography software system (version 8.2.0,
DataApex) was used for chromatogram data evaluation. Fatty acids are presented in shorthand notation, i.e. $A: B(n-x)$, where $A$ indicates the number of carbon atoms in the straight fatty acid chain, B represents the number of double bonds present, $\mathrm{n}$ represents the terminal methyl group and $\mathrm{x}$ denotes the position of the first double bond from the terminal end. Proportions of fatty acids are expressed as mass percentages of total fatty acid content.

\subsection{Compound-specific stable isotope analysis}

Carbon stable isotope ratios of fatty acid methyl esters $\left(\delta^{13} \mathrm{C}_{\mathrm{FA}}\right)$ of both POM and seal samples were analyzed using a Trace Ultra gas chromatograph (GC), a 
GC Isolink system, and a Delta V Plus isotope ratio mass spectrometer (IRMS), connected to a Conflo IV interface (Thermo Scientific Corporation). Samples were injected in splitless mode and separated on a DB-FFAP column $(60 \mathrm{~m}, 0.25 \mathrm{~mm}$ i.d., $0.25 \mu \mathrm{m}$ film thickness) using temperature programming (Kohlbach et al. 2016). The limit of detection was comparable to the methods described above. The $\delta^{13} \mathrm{C}_{\mathrm{FA}}$ values were calibrated using certified standards of $14: 0\left(\delta^{13} \mathrm{C}\right.$ : $-29.98 \%$ ) , 16:0 ( $\delta^{13} \mathrm{C}:-30.74 \%$ ) , 18:0 $\left(\delta^{13} \mathrm{C}:-23.24 \%\right.$, and 20:0 $\left(\delta^{13} \mathrm{C}:-30.68 \%\right.$ ) (supplied by Indiana University, USA). To ensure accuracy and precision ( $\pm 0.8 \%$ o for GC-IRMS), certified standards were analyzed before and after sample runs in the GC-IRMS. All reported $\delta^{13} \mathrm{C}_{\mathrm{FA}}$ values are relative to Vienna Pee Dee Belemnite (VPDB) using the standard notation $\delta^{13} \mathrm{C}_{\mathrm{FA}}(\%)=\left[\left(R_{\text {sample }} / R_{\text {standard }}\right)-1\right] \times 1000$, where $R$ is the corresponding ratio of ${ }^{13} \mathrm{C} /{ }^{12} \mathrm{C}$.

\subsection{Data analysis}

All data analyses were conducted in $\mathrm{R}$ version 4.0.2 (R Core Team 2020). The fatty acid data sets from POM and seals were visualized using correspondence analysis (CA) on non-standardized multivariate data using the vegan package (Oksanen et al. 2020). This analysis, with its inherent chi-square distance measure, was selected because of its ability to handle data zeros and compositional data (Greenacre 2011). As these characteristics are inherent in fatty acid data sets, the CA was deemed the most appropriate. Because POM was collected over a broad spatial area, the variance due to station location was removed using a canonical CA (Palmer 1993). Differences between iPOM and pPOM were then tested using a permutation test on the constrained correspondence analysis. A permutational ANOVA between harp and ringed seal fatty acid compositional data was conducted to determine if seal species differed by fatty acid composition. Tests were based on 999 free permutations to test the significance of location and species on the fatty acid profiles of POM and seal groups, respectively.

The 4 specific trophic biomarker fatty acids [16:1(n-7), 20:5(n-3), 18:4(n-3), and 22:6(n-3)] were examined in greater detail, as they were the basis of our trophic biomarker modeling approach. To increase replication and better capture variability in the $\delta^{13} \mathrm{C}_{\mathrm{FA}}$ values from pelagic POM, we included additional data originating from the same region north of Svalbard and the Nansen Basin from a study conducted in 2012 (Kohlbach et al. 2017). A Mann-
Whitney $U$-test for differences between sample years (2012 and 2017) in the biomarker fatty acid $\delta^{13} \mathrm{C}_{\mathrm{FA}}$ values found no statistical difference (significance was set at $\alpha=0.05)$. We then tested for differences among (1) the mass percentages of the trophic biomarker fatty acids between POM groups and (2) their $\delta^{13} \mathrm{C}_{\mathrm{FA}}$ values between POM groups using the nonparametric Mann-Whitney $U$-test that is robust for small data sets.

To better visualize differences in all $\delta^{13} \mathrm{C}_{\mathrm{FA}}$ values between harp and ringed seals, we chose a non-metric multidimensional scaling (NMDS) ordination because $\delta^{13} \mathrm{C}_{\mathrm{FA}}$ values are negative. Out of the 34 fatty acids present in seal blubber, 20 common fatty acids that had corresponding $\delta^{13} \mathrm{C}_{\mathrm{FA}}$ values were selected for both seal species. To determine if harp and ringed seals differed by the $\delta^{13} \mathrm{C}_{\mathrm{FA}}$ values, we conducted a permutational ANOVA between groups, based on Euclidean distance (Anderson 2017). Similar to the POM data set, we also investigated the 4 trophic biomarkers in greater detail. We used a Mann-Whitney $U$-test to test for the differences in their $\delta^{13} \mathrm{C}_{\mathrm{FA}}$ values between harp and ringed seals.

Differences between age classes in both bulk isotopes and fatty acids have been previously reported for harp and ringed seals (Lawson \& Hobson 2000, Young et al. 2010). We explored whether this difference was reflected in the $\delta^{13} \mathrm{C}_{\mathrm{FA}}$ values of the trophic biomarkers, in order to determine if age-specific modeling should be conducted. Differences between age classes (young of the year, juveniles, adults) was tested using Kruskal-Wallis rank sum tests as they are appropriate for uneven sample sizes. We found no significant difference between age classes within species groups and therefore pooled all age classes within species.

The proportional contributions of sympagic and pelagic carbon in seal blubber were estimated using the available $\delta^{13} \mathrm{C}_{\mathrm{FA}}$ values of the 4 trophic biomarker fatty acids (mean and standard deviation) of iPOM and pPOM in a Bayesian stable isotope mixing model with the MixSIAR package (Stock \& Semmens 2016a, Stock et al. 2018). Because we used the $\delta^{13} \mathrm{C}_{\mathrm{FA}}$ values of 4 biomarker fatty acids, and our question focuses on carbon sourcing to blubber, isotopic fractionation was assumed to be zero following similar studies (Budge et al. 2008, Wang et al. 2016). Mixing models were run with 50000 iterations (where the first 25000 iterations were discarded). Since the objective of this modeling approach was focused on carbon sourcing, we included a residual error term as recommended by Stock \& Semmens (2016b). Modeled estimates of proportional contri- 
butions of iPOM and pPOM in seal blubber sum to 1 $(100 \%)$. This means that seals with minimal sympagic input would have an estimated iPOM contribution near zero. Modeled outputs are reported as the mean contribution of iPOM and pPOM contributions to seal blubber, along with their standard deviation and $95 \%$ credibility intervals, i.e. Bayesian confidence intervals.

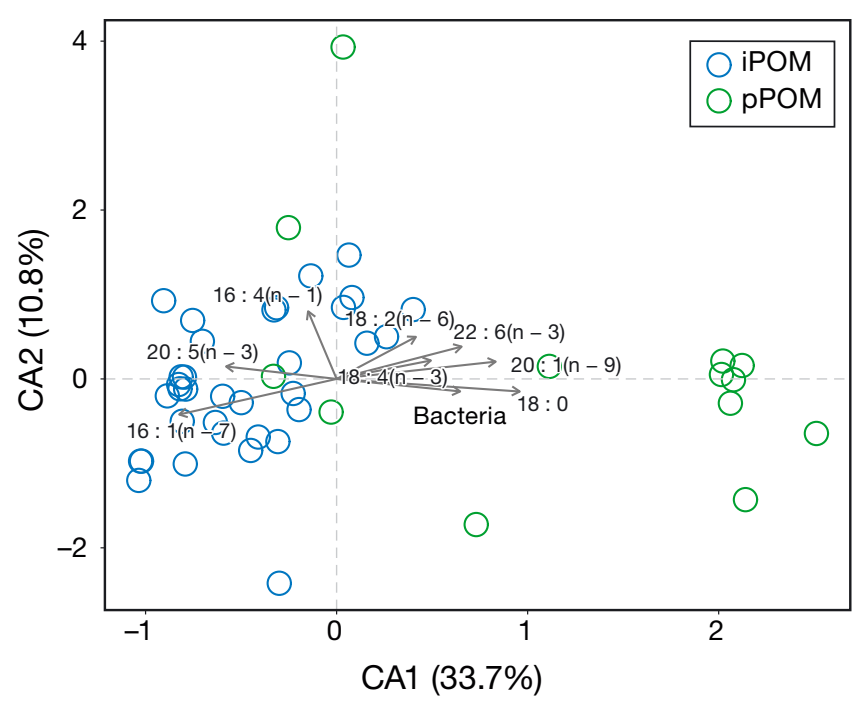

Fig. 2. Correspondence analysis (CA) biplot of 33 compositional fatty acids in particulate organic matter from sea ice (iPOM) and phytoplankton (pPOM). Biplot arrows correspond to significant contribution of fatty acids in the CA ordination. Axis labels indicate percent variance explained for each axis

\section{RESULTS}

\subsection{Particulate organic matter fatty acids and biomarker $\delta^{13} \mathrm{C}_{\mathrm{FA}}$ values}

Fatty acid composition between iPOM and pPOM was significantly different $(p=0.001)$ when accounting for the variation due to station locations. The CA axes accounted for $41 \%$ of the variability on the fatty acid composition pattern, most likely due to spatial and temporal variability (Fig. 2). Diatom marker fatty acids [16:1(n-7), 20:5(n-3), and 16:4(n-1)] contributed significantly $(\mathrm{p}=0.001)$ to the separation of iPOM from $\mathrm{pPOM}$. The dinoflagellate marker fatty acids [18:4(n-3) and 22:6(n-3)] contributed significantly ( $\mathrm{p}=$ 0.001 ) to pPOM separation, along with 18:0 and bacterial fatty acids (sum of the odd-chain saturated and branched fatty acids across stations) (Fig. 2). Of the 33 fatty acids found in all iPOM samples across stations, 3 dominated in mass contribution: 16:0 (mean $20.9 \pm 4.5 \%), 16: 1(n-7)($ mean $34.2 \pm 11.1 \%$ ) and 20:5(n-3) (mean 110+5.3\%)(Fig.3A, Table S1 in the Suppement at www.int-res.com/articles/suppl/ m675p181_supp.pdf. Of the 24 fatty acids found in all pPON samples across stations, there were again 3 that dominated: 16:0 (mean $25.5 \pm 3.3 \%$ ), 16:1(n-7) (mean $16.5 \pm 12.0 \%$ ), and 18:0 (mean 25.2 $\pm 11.0 \%$ ) (Fig. 3A, Table S1).

The mass percentages of the diatom biomarker fatty acids 16:1(n-7) and 20:5(n-3) were significantly different between POM groups ( $\mathrm{p} \leq 0.0001$, Mann-
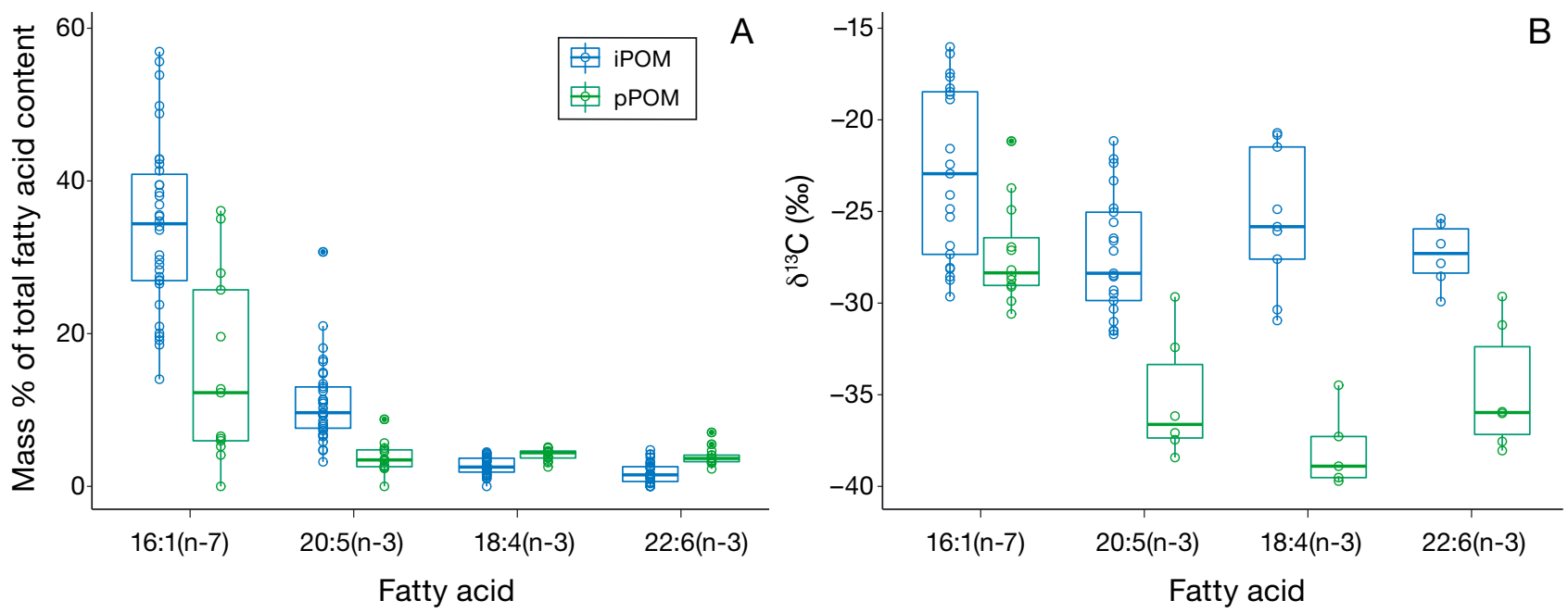

Fig. 3. Relative composition of (A) marker fatty acids and (B) their $\delta^{13} \mathrm{C}_{\mathrm{FA}}$ values compared between POM groups (iPOM: particulate organic matter from sea ice; pPOM: particulate organic matter from phytoplankton). 16:1(n-7) and 20:5(n-3) represent diatom fatty acids; $18: 4(n-3)$ and 22:6(n-3) represent dinoflagellate fatty acids. Horizontal bars within box plots indicate median proportional values; upper and lower portions of the boxes are the approximate 1st and 3rd quartiles. Vertical error bars extend towards the lowest and highest data within a range of 1.5 times the inter-quartile range. Open and closed circles represent data points (closed circles are outliers) 
Table 2. Carbon stable isotope means of available $\delta^{13} \mathrm{C}_{\mathrm{FA}}$ values for the 4 biomarker fatty acids included in this study. Mean ( \pm 1 SD) \%o values of iPOM in 2017 and 2012, pPOM in 2017 and 2012, and of harp seal blubbers sampled in 2016 and ringed seal blubbers sampled in 2017

\begin{tabular}{|lcccc|}
\hline Fatty acid & $\begin{array}{c}\text { iPOM 2017 } \\
\mathrm{n}=11 \text { stations }\end{array}$ & $\begin{array}{c}\text { pPOM (2017 \& 2012) } \\
\mathrm{n}=12 \text { stations }\end{array}$ & $\begin{array}{c}\text { Harp seals 2016 } \\
\mathrm{n}=25\end{array}$ & $\begin{array}{c}\text { Ringed seals 2017 } \\
\mathrm{n}=20\end{array}$ \\
\hline $16: 1(\mathrm{n}-7)$ & $-22.87 \pm 4.67$ & $-27.32 \pm 2.77$ & $-28.26 \pm 0.40$ & $-27.11 \pm 1.15$ \\
$20: 5(\mathrm{n}-3)$ & $-27.37 \pm 3.26$ & $-35.20 \pm 3.42$ & $-29.55 \pm 0.51$ & $-28.54 \pm 0.57$ \\
$18: 4(\mathrm{n}-3)$ & $-25.41 \pm 3.86$ & $-38.45 \pm 2.24$ & $-32.99 \pm 0.51$ & $-32.62 \pm 1.14$ \\
$22: 6(\mathrm{n}-3)$ & $-27.35 \pm 1.75$ & $-34.73 \pm 3.48$ & $-27.93 \pm 0.56$ & $-28.16 \pm 0.58$ \\
\hline
\end{tabular}

Whitney $U$-test). In comparison, the dinoflagellate biomarker fatty acids were found in relatively smaller amounts in both iPOM [18:4(n-3) mean: $2.8 \pm 1 \%$; 22:6(n-3) mean: $2.0 \pm 1.2 \%]$ and pPOM [18:4(n-3) mean: $4.1 \pm 0.8 \%$; 22:6(n-3) mean: $4.0 \pm 0.5 \%$ ] Regardless of their relative contributions to POM, they were also found to be significantly different $(\mathrm{p}<$ 0.0001, Mann-Whitney $U$-test) between POM groups (Fig. 3A).

The $\delta^{13} \mathrm{C}_{\mathrm{FA}}$ values of the 4 marker fatty acids differed significantly ( $\mathrm{p} \leq 0.005, \mathrm{Mann}$-Whitney $U$-test) between iPOM and pPOM samples, with higher $\delta^{13} \mathrm{C}$ values for iPOM (range: -27.35 to $-22.87 \%$ ) than pPOM (range: -38.45 to $-27.32 \%$ ) for each of the 4 fatty acids (Fig. 3B), enabling their use for the mixing model estimations of carbon sourcing (Table 2).

\subsection{Harp and ringed seal fatty acids and $\delta^{13} C_{F A}$ values}

Based on the relative abundance of all fatty acids found in seal blubber (Table S1), there was significant $(\mathrm{p}=0.001)$ group separation between species. The CA axes accounted for $70 \%$ of the variability in the fatty acid composition pattern (Fig. 4A). Within the first ordination axis of all fatty acids, the diatom biomarkers 16:1(n-7) and 20:5(n-3), and the dinoflagellate marker 18:4(n-3), were more prevalent in the harp seal samples, while the dinoflagellate biomarker 22:6(n-3) was more prevalent in the ringed seal samples (Fig. 4A). The separation of seal blubber composition along the first axis was primarily driven by the monounsaturated fatty acids (MUFAs) with 16, 18, and 20 carbon atoms. Both seal species had assimilated 20:1 and 22:1 MUFAs, including their specific isomers, with slightly higher levels in ringed seals. The Calanus spp. biomarker fatty acids [sum of 20:1(n-9) and 22:1(n-11)] contributed more to the ringed seals than to the harp seals. Despite group separation, the same fatty acids contributed the high-
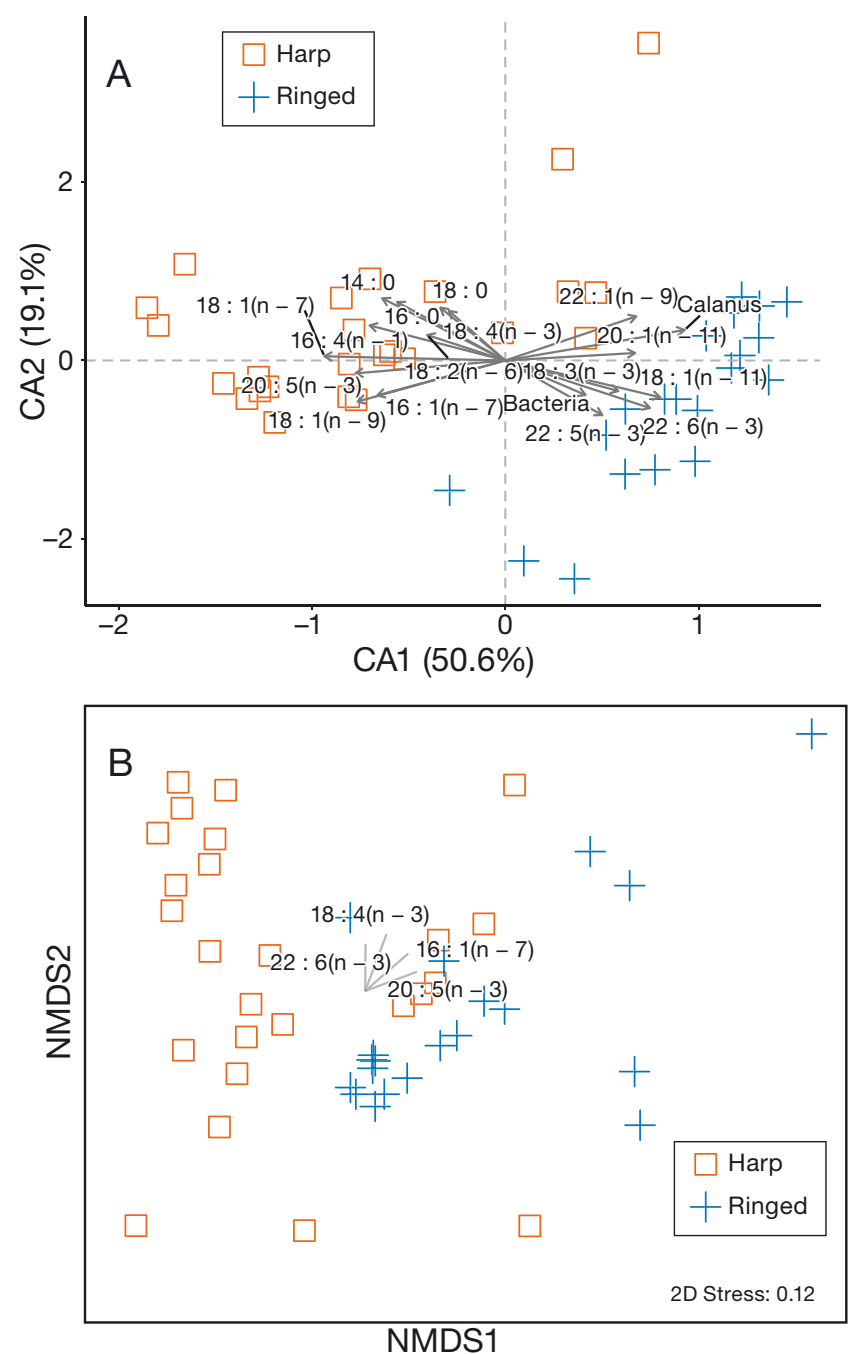

Fig. 4. Harp and ringed seal patterns of fatty acids and their carbon isotope values. (A) Correspondence analysis (CA) biplot of 34 compositional fatty acids in harp and ringed seals. Biplot arrows correspond to significant contributions from fatty acids in the CA ordination. Axis labels indicate percent variance explained for each axis. (B) Nonmetric multidimensional scaling of the $\delta^{13} \mathrm{C}_{\mathrm{FA}}$ values for 20 fatty acids in the blubber of harp and ringed seals. Biplot lines depict directions of marker fatty acids 
est mean $( \pm \mathrm{SD})$ mass percentages for both seal species: $14: 0(5.2 \pm 0.5 \%$ in harp seals, $3.3 \pm 0.3 \%$ in ringed seals), $16: 0(9.3 \pm 1.4 \%$ in harp, $7.0 \pm 1.4 \%$ in ringed), the $18: 1$ MUFA family $(26.8 \pm 1.2 \%$ in harp, $24.9 \pm 1.2 \%$ in ringed), and $20: 1(n-9)(7.7 \pm 2.3 \%$ in harp, $12.3 \pm 2 \%$ in ringed) (Table $\mathrm{S} 1$ ).

The NMDS ordination for $\delta^{13} \mathrm{C}_{\mathrm{FA}}$ values in harp and ringed seal blubber showed significant separation between the 2 seal species $(p=0.001)$, though with more overlap than the fatty acid data (Fig. 4B). The separation was prominent along NMDS axis 1 and associated with 20:5n-3 and 16:1n-7, with no separation along NMDS axis 2 . The $\delta^{13} \mathrm{C}_{\mathrm{FA}}$ values of many fatty acids fell in a similar range for both harp and ringed seals (Fig. S1 in the Supplement). For the 4 biomarker fatty acids, ringed seals had significantly higher $\delta^{13} \mathrm{C}_{\mathrm{FA}}$ values for 16:1(n-7) and 20:5(n-3) than harp seals, while there were no significant differences between the $\delta^{13} \mathrm{C}_{\mathrm{FA}}$ values for $18: 4(\mathrm{n}-3)$ and 22:6(n-3) between the seal species (Table 2, Fig. 5).

\section{3. iPOM and $\mathrm{pPOM}$ contributions to seal blubber - from mixing models}

Mixing models using the 4 trophic biomarker fatty acids estimated the proportional contribution $(1=$ $100 \%$ ) of iPOM and pPOM $\delta^{13} \mathrm{C}_{\mathrm{FA}}$ in seal blubber. Mixing models including both seal species estimated

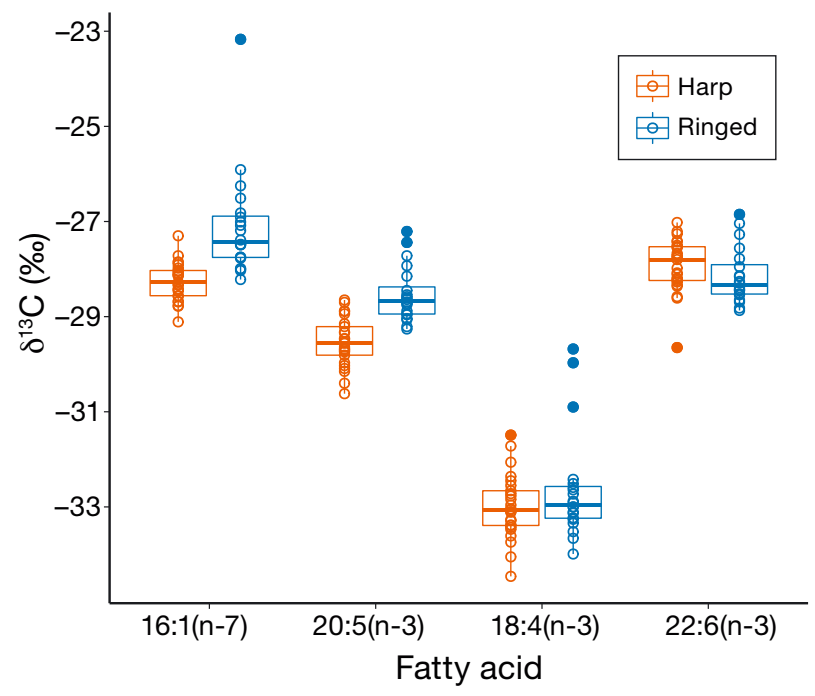

Fig. 5. Trophic biomarker $\delta^{13} \mathrm{C}_{\mathrm{FA}}$ values compared between seal species. Horizontal bars within box plots indicate median proportional values; upper and lower portions of the boxes are the approximate 1 st and 3rd quartiles. Vertical error bars extend towards the lowest and highest data within a range of 1.5 times the inter-quartile range. Open and closed circles represent data points (closed circles are outliers)
Table 3. Estimates of iPOM and pPOM contributions (mean \pm 1 SD with $95 \%$ Bayesian credible intervals) to harp (2016) and ringed (2017) seals from stable isotope mixing models using the 4 marker fatty acids (shown in Table 2)

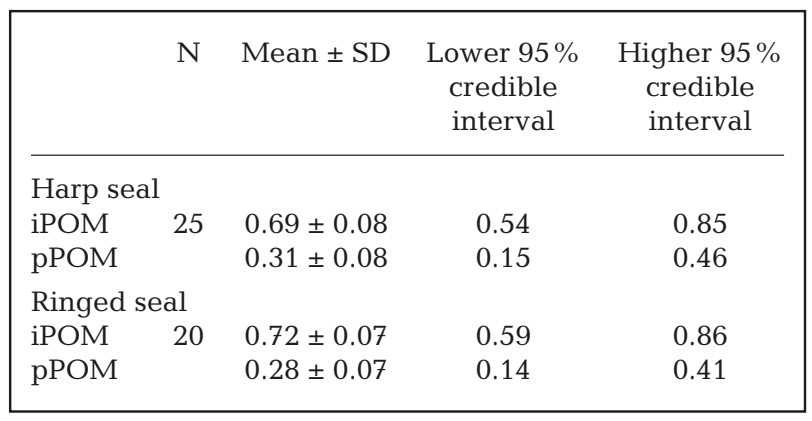

the group mean iPOM contributions to harp seals to be $0.69 \pm 0.08$ and $p P O M$ to be $0.31 \pm 0.08$. For ringed seals, mean iPOM contributions were $0.72 \pm 0.07$ and pPOM contributions were $0.28 \pm 0.07$ (Table 3 ).

\section{DISCUSSION}

\subsection{Fatty acids in $\mathrm{PPOM}$ and $\mathrm{pPOM}$}

The overall fatty acid composition in our iPOM samples was similar to that in other Arctic studies (Falk-Petersen et al. 1998, Budge et al. 2008, Kohlbach et al. 2016). The diatom marker 16:1(n-7) contributed the highest mass percentage in our iPOM samples, and the ratio of 16:1(n-7)/16:0 was $>1$ in our iPOM samples also suggesting a dominance of diatoms (Graeve et al. 1994). The second diatom marker 20:5(n-3) also had considerably higher proportions in iPOM compared to pPOM (Leu et al. 2006). Interestingly, in the Bering Sea, Wang et al. (2014) found that 20:5(n-3) contributed more than 16:1(n-7), the opposite of our findings, which could be related to differing diatom community composition or differing bloom growth conditions and phenology. Budge et al. (2008) suggested that the combination of high contributions of $16: 1(n-7)$ and low levels of polyunsaturated fatty acids (PUFAs) (in their case, $18.5 \%$ ) might be an indication of rapid algal growth conditions. The average contribution of $16: 1(n-7)$ in the present study was $34 \%$, with moderate levels of total PUFAs $(22.8 \%)$, which is not clearly indicative of rapid growth conditions. Based on metabarcoding from the sea-ice cores sampled at our ice stations in 2017, dinoflagellates were present (B. Hassett pers. comm.). This is consistent with earlier findings (Booth \& Horner 1997) and supported by the presence of 18:4(n-3) and 22:6(n-3) in our iPOM samples. Dinoflagellates and the hapto- 
phyte Phaeocystis pouchetti can be common in several Arctic ice habitats, including the snow-ice interface of first-year ice, in refrozen leads, and in melting ice (Tamelander et al. 2009, Assmy et al. 2017, Fernández-Méndez et al. 2018), and our late ice stations occurred during advanced stages of melt.

The major contributing fatty acids found in our pPOM samples were also similar to data from other Arctic food web studies (Falk-Petersen et al. 1998, Wang et al. 2014, Kohlbach et al. 2016). During a seasonal study in a High Arctic fjord (Kongsfjorden, Svalbard) near our study area, the flagellate markers 18:4(n-3) and 22:6(n-3) had even higher contributions in pPOM when compared to our values (Mayzaud et al. 2013). These findings suggest differences in nutrient availability or species composition between these areas. In addition to the protist taxa discussed, the occurrence of bacteria (the odd-chain saturated and branched fatty acids) in both iPOM and pPOM demonstrates that POM constitutes a complex mix of microbial species (Kirst \& Wiencke 1995) with strong potential for seasonal and regional changes driven by bloom phenology.

\section{2. $\delta^{13} \mathrm{C}$ differences in biomarker fatty acids between habitats}

The differences we found in the $\delta^{13} \mathrm{C}_{\mathrm{FA}}$ marker values between $\mathrm{POM}$ and $\mathrm{PPOM}$ is the key prerequisite to using these trophic markers in the subsequent mixing models. This finding is in agreement with an earlier study from the Nansen Basin when both firstyear and multi-year ice were studied (Kohlbach et al. 2016: $\delta^{13} \mathrm{C}_{\mathrm{FA}}$ iPOM: -28.4 to $-23.4 \%$; $\delta^{13} \mathrm{C}_{\mathrm{FA}} \mathrm{pPOM}$ : -39.3 to $-26.4 \%$ ) and with a study of seasonal firstyear ice in the Bering Sea (Wang et al. 2014: $\delta^{13} \mathrm{C}_{\mathrm{FA}}$ iPOM: -26.5 to $-21.0 \%$; $\delta^{13} \mathrm{C}_{\mathrm{FA}}$ pPOM: -30.4 to $-27.0 \%$ ). Leu et al. (2020) found an increasing trend in $\delta^{13} \mathrm{C}_{\mathrm{FA}}$ values in a seasonally sea-ice-covered fjord in Svalbard throughout spring (April-May), suggesting that bloom succession and an increase in underice light play a role in these values, similar to seasonal changes determined by bulk $\delta^{13} \mathrm{C}$ values. To date, studies investigating $\delta^{13} \mathrm{C}_{\mathrm{FA}}$ values of individual fatty acids in POM throughout the Arctic are not as ubiquitous compared to studies of bulk $\delta^{13} \mathrm{C}$ POM. Isotopic enrichment in bulk $\delta^{13} \mathrm{C}$ values in iPOM over pPOM is seasonally and regionally variable, depending on environmental and physiological factors in addition to taxonomic community composition and biomass, which can be minimal or absent at times (de la Vega et al. 2019, Leu et al. 2020).

\subsection{Fatty acid composition of harp and ringed seals}

Although we cannot determine exactly where the harp seals from this study were foraging, it is likely they were following the sea-ice-edge in the weeks or months before collection (Stenson et al. 2020). The presence of the Calanus spp. trophic biomarkers in their blubber suggest that they were feeding on a Calanus spp.-derived food chain (Sargent \& FalkPetersen 1988). This food chain supports a variety of their major prey items. During late summer and early autumn in the northern Barents Sea, harp seals feed on pelagic crustaceans such as krill (Thysanoessa spp.), hyperiid amphipods Themisto libellula, and polar cod (Lydersen et al. 1991, Nilssen et al. 1995b, Falk-Petersen et al. 2004). These species, also supported by the Calanus spp. food chain, can have high levels of 16:1(n-7) and 20:5(n-3) (Auel et al. 2002, Falk-Petersen et al. 2000, Kohlbach et al. 2017).

The diet of ringed seals is often dominated by polar cod (e.g. Labansen et al. 2007), but they also consume a mix of other fishes and crustaceans (Gjertz \& Lydersen 1986, Weslawski et al. 1994). Along the west coast of Svalbard, ringed seal diet (determined from the same fjord as the animals in the present study) has recently been shown to be dominated by polar cod (Bengtsson et al. 2020). 16:1(n-7) and 20:5(n-3), while slightly lower in ringed seals than in harp seals, were still major contributing fatty acids, similar to that found in previous studies (Thiemann et al. 2007, Cooper et al. 2009). Regardless of season, ringed seals from the Bering and Chukchi Seas (Wang et al. 2016) had higher contributions of 16:1(n-7), 20:5(n-3), and 22:6(n-3), and lower contributions of $18: 4(n-3)$ than the ringed seals from this study, potentially resulting from differences in the biomarkerproducing algal communities as indicated in the observed differences in the $\mathrm{PPOM}$ and pPOM fatty acids (Wang et al. 2014).

\subsection{Carbon sourcing to seal diets}

Based on the 4 specific trophic biomarkers, we found that part of the species separation is due to significantly higher $\delta^{13} \mathrm{C}_{\mathrm{FA}}$ values of $16: 1(\mathrm{n}-7)$ and 20:5(n-3) in ringed seals compared to harp seals. This finding indicates that ringed seals assimilated more sympagic fatty acids compared to harp seals. Our ringed seals had similar $\delta^{13} \mathrm{C}_{\mathrm{FA}}$ values of the diatom marker 20:5(n-3) $(-28.5 \%)$ to Bering Sea ringed seals $(-29.2 \%$; Wang et al. 2016), yet were more negative when compared to ringed seals from land-fast ice in 
Utqiaġvik, Alaska (-26.4\%) (Budge et al. 2008). For the $\delta^{13} C_{F A}$ values for $18: 4(n-3)$ and $22: 6(n-3)$, the ringed seals in this study had higher values compared to the ringed seals in the Bering Sea (Wang et al. 2016). No comparable values are currently available for harp seals.

Our modeling results showed that both harp and ringed seal diets are strongly supported by sea-icederived carbon sources. It should be noted that in addition to different carbon sources, other factors might be contributing to these differences (see section 4.5). Regardless of year or region, earlier studies also found that harp seal diet is supported by sea-ice production and a diatom-based food web (Falk-Petersen et al. 2004, 2009). In late summer and early autumn, harp seals maintain strong affinities to the marginal ice zone (Folkow et al. 2004, Nordøy et al. 2008), due to the seasonally strong pulses of marine productivity in this area (Falk-Petersen et al. 1990, Wassmann et al. 2020). Modeled results of sea-ice-derived carbon contributions to various harp seal prey items found that iPOM contributed up to $55 \%$ in the amphipod T. libellula (Kohlbach et al. 2016), and up to $65 \%$ in polar cod (Kohlbach et al. 2017). If we follow the sea-ice carbon pathway from the prey of the seals, it is plausible that at the time of the year the harp seals in this study were collected (before their long southward migration), sympagic carbon sources contributed more to their diet than pelagic carbon.

For ringed seals, the maximum value estimates of sea-ice-derived carbon contributions were similarly high when compared to other modeled values. In the Pacific Arctic, sea-ice-derived carbon in ringed seal blubber ranged from 24 to $60 \%$ in the Bering Sea, depending on time of year (Wang et al. 2016), and up to $62 \%$ in land-fast ice off the coast of Utqiagivik, Alaska (Budge et al. 2008). Despite minor methodological differences between the studies, there is strong overall agreement on the high contributions of ice-derived carbon to ringed seal diets. Land-fast ice is seasonally present where the ringed seals from this study were captured (Nilsen et al. 2008), which could have potentially supported the high sympagic contributions found in their blubber. In turn, land-fast ice can contain substantial amounts of ice algae that become available for the marine food web (Thyrring et al. 2017). Similar to harp seals, ringed seals replenish energy stores that were used during the spring (Ryg et al. 1990, Young \& Ferguson 2013). An alternative to land-fast ice-derived carbon sources, late summer/early autumn foraging trips to the ice edge (Freitas et al. 2008, Lone et al. 2019) could also explain the high iPOM contributions in their blub- ber. Based on the methods applied in our study, we conclude that both species of ice seals had substantial contributions of sea-ice-derived organic carbon in their diets (which were reflected in their blubber). These data are consistent with observations from other Arctic areas for both ice seals and their prey.

\subsection{Model sensitivity and caveats}

Modeling carbon contributions from sea ice and phytoplankton to blubber in near-apex predators warrants a discussion of both model sensitivities and caveats.

\subsubsection{Issue 1}

The fatty acid biomarkers used for this study were selected because they remain unmodified as they move through the marine food web (Dalsgaard et al. 2003). Almost all PUFAs originate from primary producers but can undergo trophic modifications as they pass upwards in a food chain (Bell \& Tocher 2009). Vertebrates are unable to synthesize PUFAs de novo, and these essential fatty acids must be acquired through their diet (Tinoco 1982). However, vertebrates possess metabolic pathways to further desaturate and elongate the n-3 PUFAs (Rosenthal 1987) to form other highly unsaturated fatty acids (Bell \& Tocher 2009). It has been shown that some pinniped species can modify various dietary fatty acids differently while consuming the same prey type, demonstrating the variability of assimilation within consumers (Rosen \& Tollit 2012). Therefore, we combined fatty acids with their $\delta^{13} \mathrm{C}_{\mathrm{FA}}$ values in our study, in order to provide a finer resolution of the trophic biomarkers of interest.

\subsubsection{Issue 2}

It is well known that Bayesian model results can be skewed when not accounting for trophic fractionation (i.e. the amount of variation in the $\delta^{13} \mathrm{C}$ and $\delta^{15} \mathrm{~N}$ values between prey and predators) in bulk carbon and nitrogen isotopes in diet reconstruction studies (Bond \& Diamond 2011). Our study avoided this potential pitfall because we worked with compoundspecific stable isotope values of carbon of individual trophic marker fatty acids. However, we assume here that fatty acids are integrated into seal blubber with little to no modification of their carbon chain, thus displaying unchanged $\delta^{13} \mathrm{C}_{\mathrm{FA}}$ values (Issue 1). Iso- 
topic fractionation, particularly for 2 of the primary producer fatty acids used in this study, was found to be negligible for Arctic eider ducks (Polysticta stelleri and Somateria fischeri) and Atlantic pollock Pollachius virens (Budge et al. 2011, 2016). Experimental work on these vertebrate species found no trophic discrimination of the 20:5(n-3) and 22:6(n-3) $\delta^{13} \mathrm{C}_{\mathrm{FA}}$ values in either adipose tissue or serum, suggesting unmodified uptake of these fatty acids (Budge et al. 2011, 2016). These findings would then justify subsequent studies using no fractionation factor when quantifying carbon contributions to diet using trophic marker fatty acids (Kohlbach et al. 2016, 2017, Wang et al. 2016). The modeled results of sea-ice carbon to seal prey in this region (see section 4.4) would hence further support the relatively high contributions we found in the modeled results for seals. Using the $\delta^{13} \mathrm{C}_{\mathrm{FA}}$ values of only 20:5(n-3) and 22:6(n-3) in our mixing model (rather than all four), for comparability with Wang et al. (2016), the estimated contributions of sympagic carbon in seal blubber were even higher for both species in the present study ( $\geq 79 \%)$. These differences show that the mixing model approach is also sensitive to which fatty acids are chosen as biomarkers for diatoms and dinoflagellates.

Including isotopic fractionation terms into the model would certainly be more accurate, but to our knowledge only few data are available for higher marine organisms (see above). Furthermore, experimental work has shown that $\delta^{13} \mathrm{C}_{\mathrm{FA}}$ values of PUFAs can also be modified via fractionation when being incorporated into lipids in various tissues (Gladyshev et al. 2016), or by metabolic processes (Chiapella et al. 2021). Although it is difficult to map the individual steps of isotopic fractionation into total metabolism, we recognize a need for increased attention towards the kinetics of metabolic processes. This will better our understanding of the processes that cause fractionation, resulting in better application of $\delta^{13} \mathrm{C}_{\mathrm{FA}}$ values in quantitative models. Nonetheless, our results can be over- or under-estimations due to shifting trophic baselines in aquatic ecosystems (de la Vega et al. 2019, Casey \& Post 2011) and the complexities of isotopic discrimination in marine mammals (Newsome et al. 2010).

\subsubsection{Issue 3}

We found high contributions of iPOM in the seals' diets. This result is, at first sight, surprising given that the contribution of sea-ice production is generally lower than pelagic primary production and the pro- ductive season in ice is short and regionally variable in seasonal ice-covered regions. Sympagic production in the Barents Sea along the spring ice edge ranges between 4.9 and $55 \mathrm{mg}(0.0049-0.055 \mathrm{~g}) \mathrm{C}$ $\mathrm{m}^{-2} \mathrm{~d}^{-1}$ (McMinn \& Hegseth 2007), which is at least one order of magnitude below pelagic gross primary production in this region, which is estimated at 0.19 to $0.85 \mathrm{~g} \mathrm{C} \mathrm{m}^{-2} \mathrm{~d}^{-1}$ (Svensen et al. 2019). Ice algal production in the Northern Barents Sea is estimated to be approximately $5.3 \mathrm{~g} \mathrm{C} \mathrm{m}^{-2} \mathrm{yr}^{-1}$ (Hegseth 1998), while the deep Arctic basins can have daily rates as high as 0.013 to $0.069 \mathrm{~g} \mathrm{C} \mathrm{m}^{-2} \mathrm{~d}^{-1}$ (Gosselin et al. 1997, Fernández-Méndez et al. 2015). Again, this annual estimate is well below the phytoplankton production on the nutrient-rich inflow shelves such as the Barents Sea (over $70 \mathrm{~g} \mathrm{C} \mathrm{m}^{-2} \mathrm{yr}^{-1}$ ) but in the same range as phytoplankton production in the central Arctic Ocean (Wiedmann et al. 2020). It should be noted that the highest phytoplankton production contributions occur in ice-free areas and, as such, might not be an important carbon source for the icebased seals. Consequently, if seal foraging occurred over large parts off the shelves in deep ice-covered Arctic waters or if they spent a considerable amount of time close to sea ice, relatively high contributions of ice algal carbon could be expected.

\subsubsection{Issue 4}

Assumptions were made with spatial and temporal variability of POM, and sampling did not always occur within optimal time frames. We sampled POM from a large geographic area, in order to capture more of the variation of the $\delta^{13} \mathrm{C}_{\mathrm{FA}}$ values. We believe this was an appropriate approach, given that these seals are highly mobile predators within the European Arctic.

Pelagic $\delta^{13} \mathrm{C}_{\mathrm{FA}}$ values were included from a different year, which is suboptimal because sea-ice- and pelagic-derived carbon sources likely vary in their contribution to consumers temporally (as well as spatially). While the temporal mismatch between sampling of carbon end members and seal sampling is not ideal, we argue that the variation in pPOM carbon isotope values has been shown to be rather minor between years and seasons in the study area region (Søreide et al. 2006: bulk $\delta^{13} \mathrm{C}$ : -24.6 to $-21 \%$; Tamelander et al. 2006: bulk $\delta^{13} \mathrm{C}:-26.5$ to $-23.0 \%$ ). When comparing $\delta^{13} \mathrm{C}_{\mathrm{FA}}$ values, our pPOM values are similar to published results from the Nansen Basin (see section 4.2). iPOM values, however, are both regionally and seasonally variable in this and 
other study areas, but interannual variation is not higher than seasonal and regional variation of iPOM (Søreide et al. 2006, Tamelander et al. 2006).

We did not always sample seal tissues in the optimal time frame relative to source turnover. The slight off-set of end-member sampling and seal sampling is preferred because of the turnover time needed to assimilate dietary fatty acids in seal blubber (Tollit et al. 2010). Fatty acids found in blubber reflect a time period of weeks to several months for seals (Nordstrom et al. 2008, Tollit et al. 2010). We hence evaluate the mismatch of end-member sampling and seal sampling as comparatively minor for $\mathrm{pPOM}$, though iPOM estimates could be more heavily affected. Given that our estimates of iPOM contributions are very high, even a somewhat lower estimate would not change the conclusion substantially, since estimates of $40-60 \%$ iPOM contribution would still be considered high and confirm the conclusion of a strong and rather similar ice association for both species. Seasonal or monthly variation in the contribution of iPOM can be expected (Wang et al. 2016) but was not resolved in our study.

\section{CONCLUSIONS}

In summary, we found differences in both fatty acids and the $\delta^{13} \mathrm{C}_{\mathrm{FA}}$ values of specific trophic biomarkers in sympagic algae and phytoplankton as hypothesized. In contrast to our expectations, the 2 seal species were strongly separated in all fatty acid patterns, indicating a significant degree of dietary niche separation. Even though we found no differences in age classes for the 4 trophic biomarkers, our sample sizes were relatively small and disproportionate within age classes; hence, we recommend a complementary study where age-class differences could be more thoroughly explored. Finally, we hypothesized that sympagic carbon would be more likely to contribute to the diet of ringed seals because of their stronger association with sea ice. Instead, we found that sympagic carbon supported both harp and ringed seals similarly over the summer and into autumn (June, August, and September).

Since 2011, the Eurasian Basin has been almost ice free at the end of summer, with $<10 \%$ sea-ice coverage remaining, and this area has experienced a continual northward retreat of sea-ice extent (Polyakov et al. 2017). Concomitantly, occurrences of new Atlantic fish species have been found in ringed seal diet (Bengtsson et al. 2020), as these boreal species expand into the Arctic (Renaud et al. 2012). Regard- less of these changes, sea ice is still seasonally present within the European Arctic, and both harp and ringed seals continue to associate with this habitat. Their continued association with sea ice is reflected in their foraging behavior (Hamilton et al. 2016, 2021) and migratory patterns (Stenson et al. 2020), and is still apparent in the carbon sourcing to their diet (the present study). Given the current state of sea-ice loss in the Northern Barents Sea (Perovich et al. 2020), it remains to be seen if these seals will transition to a more open-water dominated lifestyle and diet, opt for potentially longer migration routes to the ice edge, or experience population size declines.

Acknowledgements. Funding for this project was provided by the Norwegian Research Council, Arctic ABC Project (project no. 244319) for E.H.K., B.A.B., and Ø.V. R.G. was supported by Arctic SIZE jointly funded by UiT The Arctic University of Norway and the Tromsø Research Foundation (no. 01vm/h15). Svalbard collections and K.M.K. and C.L.'s engagement in the project were financed by the Norwegian Polar Institute. A mobility grant provided by UiT assisted in research visits at the Alfred Wegener Institute (AWI) in Bremerhaven, Germany. We thank the captain and crew of the RV 'Polarstern' expedition PS106 for their field support. We acknowledge Jørgen Berge and the Arctic ABC project for their support, including Malin Daase for assistance with Fig. 1. We also thank Doreen Kohlbach and Rob Rolls for the many fruitful discussions during the development of this paper. We are especially grateful to Valeria Adrian, Dieter Janssen, Ruth Alheit, and Sinah Müller for their assistance and guidance with laboratory work and analysis while at AWI, and to Boris Koch and the AWI Ecological Chemistry Group for their support during research stays. We thank the editor, Keith Hobson, as well as Shiway Wang and three anonymous reviewers, for helpful and constructive comments which improved this manuscript.

\section{LITERATURE CITED}

Anderson MJ (2017) Permutational multivariate analysis of variance (PERMANOVA). In: Balakrishnan N, Colton $\mathrm{T}$, Everitt B, Piegorsch W, Ruggeri F, Teugels JL (eds) Wiley StatsRef: Statistics Reference Online. Wiley, p 1-15

*Assmy P, Fernández-Méndez M, Duarte P, Meyer A and others (2017) Leads in Arctic pack ice enable early phytoplankton blooms below snow-covered sea ice. Sci Rep 7:40850

Auel H, Harjes M, da Rocha R, Stübing D, Hagen W (2002) Lipid biomarkers indicate different ecological niches and trophic relationships of the Arctic hyperiid amphipods Themisto abyssorum and T. libellula. Polar Biol 25: 374-383

Bell MV, Tocher DR (2009) Biosynthesis of polyunsaturated fatty acids in aquatic ecosystems: general pathways and new directions. In: Arts MT, Brett MT, Kainz MJ (eds) Lipids in aquatic ecosystems. Springer, Dordrecht, p 211-236

* Bengtsson O, Lydersen C, Kovacs KM, Lindstrøm U (2020) Ringed seal (Pusa hispida) diet on the west coast of Spits- 
bergen, Svalbard, Norway: during a time of ecosystem change. Polar Biol 43:773-788

Bond AL, Diamond AW (2011) Recent Bayesian stable-isotope mixing models are highly sensitive to variation in discrimination factors. Ecol Appl 21:1017-1023

Booth BC, Horner RA (1997) Microalgae on the Arctic Ocean section, 1994: species abundance and biomass. Deep Sea Res II 44:1607-1622

* Budge SM, Wooller MJ, Springer AM, Iverson SJ, McRoy CP, Divoky GJ (2008) Tracing carbon flow in an Arctic marine food web using fatty acid-stable isotope analysis. Oecologia 157:117-129

Budge SM, Wang SW, Hollmén TE, Wooller MJ (2011) Carbon isotopic fractionation in eider adipose tissue varies with fatty acid structure: implications for trophic studies. J Exp Biol 214:3790-3800

* Budge SM, Aucoin LR, Ziegler SE, Lall SP (2016) Fractionation of stable carbon isotopes of tissue fatty acids in Atlantic pollock (Pollachius virens). Ecosphere 7:e01437

Burian A, Nielsen JM, Hansen T, Bermudez R, Winder M (2020) The potential of fatty acid isotopes to trace trophic transfer in aquatic food-webs. Philos Trans R Soc Lond B Biol Sci 375:20190652

Casey MM, Post DM (2011) The problem of isotopic baseline: reconstructing the diet and trophic position of fossil animals. Earth Sci Rev 106:131-148

* Castellani G, Schaafsma FL, Arndt S, Lange BA and others (2020) Large-scale variability of physical and biological sea-ice properties in polar oceans. Front Mar Sci 7:536

Chiapella AM, Kainz MJ, Strecker AL (2021) Fatty acid stable isotopes add clarity, but also complexity, to tracing energy pathways in aquatic food webs. Ecosphere 12: e03360

Cooper MH, Budge SM, Springer AM, Sheffield G (2009) Resource partitioning by sympatric pagophilic seals in Alaska: monitoring effects of climate variation with fatty acids. Polar Biol 32:1137-1145

Cusset F, Fort J, Mallory M, Braune B, Massicottte P, Massé G (2019) Arctic seabirds and shrinking sea ice: egg analyses reveal the importance of ice-derived resources. Sci Rep 9:15405

* Dalsgaard J, St. John M, Kattner G, Müller-Navarra D, Hagen W (2003) Fatty acid trophic markers in the pelagic marine environment. Adv Mar Biol 46:225-340

de la Vega C, Jeffreys RM, Tuerena R, Ganeshram R, Mahaffey C (2019) Temporal and spatial trends in marine carbon isotopes in the Arctic Ocean and implications for food web studies. Glob Change Biol 25:4116-4130

Falk-Petersen S, Hopkins CCE, Sargent JR (1990) Trophic relationships in the pelagic arctic food web. In: Barnes M, Gibson RN (eds) Trophic relationships in the marine environment. Proc 24th Eur Mar Biol Symp. Aberdeen University Press, Aberdeen, p 315-333

Falk-Petersen S, Sargent JR, Henderson J, Hegseth EN, Hop H, Okilodkov YB (1998) Lipids and fatty acids in ice algae and phytoplankton from the marginal ice zone in the Barents Sea. Polar Biol 20:41-47

Falk-Petersen S, Hop H, Budgell WP, Hegseth E and others (2000) Physical and ecological processes in the marginal ice zone of the northern Barents Sea during the summer melt period. J Mar Syst 27:131-159

Falk-Petersen S, Haug T, Nilssen KT, Wold A, Dahl TM (2004) Lipids and trophic linkages in harp seal (Phoca groenlandica) from the eastern Barents Sea. Polar Res 23:43-50
Falk-Petersen S, Haug T, Hop H, Nilssen KT, Wold A (2009) Transfer of lipids from plankton to blubber of harp and hooded seals off East Greenland. Deep Sea Res II 56: 2080-2086

*Fernández-Méndez M, Katlein C, Rabe B, Nicolaus M and others (2015) Photosynthetic production in the central Arctic Ocean during the record sea-ice minimum in 2012. Biogeosciences 12:3525-3549

*Fernández-Méndez M, Olsen LM, Kauko HM, Meyer A and others (2018) Algal hot spots in a changing Arctic Ocean: sea-ice ridges and the snow-ice interface. Front Mar Sci $5: 75$

Fetterer F, Knowles K, Meier WN, Savoie M, Windnagel AK (2017) Sea Ice Index, Version 3. [G02135]. Boulder, CO. NSIDC: National Snow and Ice Data Center. doi: 10.7265/N5K072F8

Folch J, Lees M, Stanley GHS (1957) A simple method for the isolation and purification of total lipides from animal tissues. J Biol Chem 226:497-509

* Folkow LP, Nordøy ES, Blix AS (2004) Distribution and diving behaviour of harp seals (Pagophilus groenlandicus) from the Greenland Sea stock. Polar Biol 27:281-298

*Freitas C, Kovacs KM, Ims RA, Fedak MA, Lydersen C (2008) Ringed seal post-moulting movement tactics and habitat selection. Oecologia 155:193-204

Fry B, Sherr EB (1984) ${ }^{13} \mathrm{C}$ measurements as indicators of carbon flow in marine and freshwater ecosystems. Contrib Mar Sci 27:12-47

Gjertz I, Lydersen C (1986) The ringed seal (Phoca hispida) spring diet in northwestern Spitsbergen, Svalbard. Polar Res 4:53-56

* Gladyshev MI, Makhutova ON, Kravchuk ES, Anishchenko OV, Sushchik NN (2016) Stable isotope fractionation of fatty acids of Daphnia fed laboratory cultures of microalgae. Limnologica 56:23-29

KGosselin M, Levasseur M, Wheeler PA, Horner RA, Booth BC (1997) New measurements of phytoplankton and ice algal production in the Arctic Ocean. Deep Sea Res II 44: 1623-1644

* Gradinger R (2009) Sea-ice algae: major contributors to primary production and algal biomass in the Chukchi and Beaufort Seas during May/June 2002. Deep Sea Res II 56:1201-1212

K Graeve M, Kattner G, Hagen W (1994) Diet-induced changes in the fatty acid composition of Arctic herbivorous copepods: experimental evidence of trophic markers. J Exp Mar Biol Ecol 182:97-110

Greenacre M (2011) Measuring subcompositional incoherence. Math Geosci 43:681-693

* Hamilton CD, Lydersen C, Ims RA, Kovacs KM (2015) Predictions replaced by facts: a keystone species' behavioural responses to declining Arctic sea-ice. Biol Lett 11: 20150803

* Hamilton CD, Lydersen C, Ims RA, Kovas KM (2016) Coastal habitat use by ringed seals Pusa hispida following a regional sea-ice collapse: importance of glacial refugia in a changing Arctic. Mar Ecol Prog Ser 545:261-277

*Hamilton CD, Kovacs KM, Ims RA, Aars J, Lydersen C (2017) An Arctic predator-prey system in flux: climate change impacts on space use by polar bears and ringed seals. J Anim Ecol 86:1054-1064

*Hamilton CD, Vacquié-Garcia J, Kovacs KM, Ims RA, Kohler J, Lydersen C (2019) Contrasting changes in space use induced by climate change in two Arctic marine mammal species. Biol Lett 15:20180834 
Hamilton CD, Lydersen C, Aars J, Biuw M and others (2021) Marine mammal hotspots in the Greenland and Barents Seas. Mar Ecol Prog Ser 659:3-28

Haug T, Nilssen KT, Øien N, Potelov V (1994) Seasonal distribution of harp seals (Phoca groenlandica) in the Barents Sea. Polar Res 13:163-172

Hegseth EN (1998) Primary production of the northern Barents Sea. Polar Res 17:113-123

Holst M, Stirling I, Hobson KA (2001) Diet of ringed seals (Phoca hispida) on the east and west sides of the North Water Polynya, northern Baffin Bay. Mar Mamm Sci 17: 888-908

*Horner R, Schrader GC (1982) Relative contributions of ice algae, phytoplankton, and benthic microalgae to primary production in nearshore regions of the Beaufort Sea. Arctic 35:485-503

Ji R, Jin M, Varpe $\varnothing$ (2013) Sea ice phenology and timing of primary production pulses in the Arctic Ocean. Glob Change Biol 19:734-741

Jónasdóttir SH (2019) Fatty acid profiles and production in marine phytoplankton. Mar Drugs 17:151

Kattner G, Fricke HS (1986) Simple gas-liquid chromatographic method for the simultaneous determination of fatty acids and alcohols in wax esters of marine organisms. J Chromatogr A 361:263-268

Kennedy H, Thomas DN, Kattner G, Haas C, Dieckmann GS (2002) Particulate organic matter in Antarctic summer sea ice: concentration and stable isotopic composition. Mar Ecol Prog Ser 238:1-13

Kirst GO, Wiencke C (1995) Ecophysiology of polar algae. J Phycol 31:181-199

Kohlbach D, Graeve M, Lange BA, David C, Peeken I, Flores $H$ (2016) The importance of ice algae-produced carbon in the central Arctic Ocean ecosystem: food web relationships revealed by lipid and stable isotope analyses. Limnol Oceanogr 61:2027-2044

Kohlbach D, Schaafsma FL, Graeve M, Lebreton B and others (2017) Strong linkage of polar cod (Boreogadus saida) to sea ice algae-produced carbon: evidence from stomach content, fatty acid and stable isotope analyses. Prog Oceanogr 152:62-74

Kovacs KM, Lydersen C, Overland JE, Moore SE (2011) Impacts of changing sea-ice conditions on Arctic marine mammals. Mar Biodivers 41:181-194

*Labansen AL, Lydersen C, Haug T, Kovacs KM (2007) Spring diet of ringed seals (Phoca hispida) from northwestern Spitsbergen, Norway. ICES J Mar Sci 64:1246-1256

* Laidre KL, Stirling I, Lowry LF, Wiig Ø, Heide-Jørgensen MP, Ferguson SH (2008) Quantifying the sensitivity of Arctic marine mammals to climate-induced habitat change. Ecol Appl 18:S97-S125

Lawson JW, Hobson KA (2000) Diet of harp seals (Pagophilus groenlandicus) in nearshore northeast Newfoundland: inferences from stable-carbon $\left(\delta^{13} \mathrm{C}\right)$ and nitrogen $\left(\delta^{15} \mathrm{~N}\right)$ isotope analyses. Mar Mamm Sci 16:578-591

* Lee RF, Nevenzel JC, Paffenhöfer GA (1971) Importance of wax esters and other lipids in the marine food chain: phytoplankton and copepods. Mar Biol 9:99-108

Leu E, Falk-Petersen S, Kwaśniewski S, Wulff A, Edvardsen K, Hessen DO (2006) Fatty acid dynamics during the spring bloom in a High Arctic fjord: importance of abiotic factors versus community changes. Can J Fish Aquat Sci 63:2760-2779

Leu E, Brown TA, Graeve M, Wiktor J and others (2020) Spatial and temporal variability of ice algal trophic markers - with recommendations about their application. J Mar Sci Eng 8:676

Lindstrøm U, Nilssen KT, Pettersen LMS, Haug T (2013) Harp seal foraging behaviour during summer around Svalbard in the northern Barents Sea: diet composition and the selection of prey. Polar Biol 36:305-320

Kone K, Hamilton CD, Aars J, Lydersen C, Kovacs KM (2019) Summer habitat selection by ringed seals (Pusa hispida) in the drifting sea ice of the northern Barents Sea. Polar Res 38:1-10

Lydersen C, Gjertz I (1987) Population parameters of ringed seals (Phoca hispida Schreber, 1775) in the Svalbard area. Can J Zool 65:1021-1027

Lydersen C, Angantyr LA, Wiig Ø, Øritsland T (1991) Feeding habits of Northeast Atlantic harp seals (Phoca groenlandica) along summer ice edge of the Barents Sea. Can J Fish Aquat Sci 48:2180-2183

MacArthur RH (1958) Population ecology of some warblers of northeastern coniferous forests. Ecology 39:599-619

* Mayzaud P, Boutoute M, Noyon M, Narcy F, Gasparini S (2013) Lipid and fatty acids in naturally occurring particulate matter during spring and summer in a high arctic fjord (Kongsfjorden, Svalbard). Mar Biol 160:383-398

*McMahon KW, Ambrose WG Jr, Johnson BJ, Sun MY, Lopez GR, Clough LM, Carroll ML (2006) Benthic community response to ice algae and phytoplankton in Ny Ålesund, Svalbard. Mar Ecol Prog Ser 310:1-14

* McMinn A, Hegseth EN (2007) Sea ice primary productivity in the northern Barents Sea, spring 2004. Polar Biol 30: 289-294

Middelburg JJ (2014) Stable isotopes dissect aquatic food webs from the top to the bottom. Biogeosciences 11: 2357-2371

*Newsome SD, Clementz MT, Koch PL (2010) Using stable isotope biogeochemistry to study marine mammal ecology. Mar Mamm Sci 26:509-572

Nilsen F, Cottier F, Skogset R, Mattsson S (2008) Fjord-shelf exchanges controlled by ice and brine production: the interannual variation of Atlantic Water in Isfjorden, Svalbard. Cont Shelf Res 28:1838-1853

Nilssen KT, Haug T, Potelov V, Stasenkov VA, Timoshenko YK (1995a) Food habits of harp seals (Phoca groenlandica) during lactation and moult in March-May in the southern Barents Sea and White Sea. ICES J Mar Sci 52:33-41

* Nilssen KT, Haug T, Potelov V, Timoshenko YK (1995b) Feeding habits of harp seals (Phoca groenlandica) during early summer and autumn in the northern Barents Sea. Polar Biol 15:485-493

Nilssen KT, Haug T, Grotnes PE, Potelov V (1997) Seasonal variation in body condition of adult Barents Sea harp seals (Phoca groenlandica). J Northwest Atl Fish Sci 22:17-25

*Nordøy ES, Folkow LP, Potelov V, Prischemikhin V, Blix AS (2008) Seasonal distribution and dive behaviour of harp seals (Pagophilus groenlandicus) of the White Sea-Barents Sea stock. Polar Biol 31:1119-1135

Nordstrom CA, Wilson LJ, Iverson SJ, Tollit DJ (2008) Evaluating quantitative fatty acid signature analysis (QFASA) using harbour seals Phoca vitulina richardsi in captive feeding studies. Mar Ecol Prog Ser 360:245-263

Øigård TA, Lindstrøm U, Haug T, Nilssen KT, Smout S (2013) Functional relationship between harp seal body condition and available prey in the Barents Sea. Mar Ecol Prog Ser 484:287-301

Oksanen J, Guillaume Blanchet F, Friendly M, Kindt R and others (2020) vegan: Community Ecology Package. R pack- 
age version 2.5-7. https://CRAN.R-project.org/package= vegan (accessed 1 Dec 2020)

Palmer MW (1993) Putting things in even better order: the advantages of canonical correspondence analysis. Ecology 74:2215-2230

Perovich D, Meier W, Tschudi M, Hendricks S and others (2020) Sea ice. In: Richter-Menge J, Druckenmiller ML, Jeffries M (eds) Arctic Report Card 2020 doi:10.25923/ n170-9h57

Polyakov IV, Pnyushkov AV, Alkire MB, Ashik IM and others (2017) Greater role for Atlantic inflows on sea-ice loss in the Eurasian Basin of the Arctic Ocean. Science 356: 285-291

R Core Team (2020) R: a language and environment for statistical computing. R Foundation for Statistical Computing, Vienna. https://www.R-project.org/

Reitan KI, Rainuzzo JR, Olsen Y (1994) Effect of nutrient limitation on fatty acid and lipid content of marine microalgae. J Phycol 30:972-979

Renaud PE, Berge J, Varpe Ø, Lønne OJ, Nahrgang J, Ottesen C, Hallanger I (2012) Is the poleward expansion by Atlantic cod and haddock threatening native polar cod, Boreogadus saida? Polar Biol 35:401-412

Rosen DAS, Tollit DJ (2012) Effects of phylogeny and prey type on fatty acid calibration coefficients in three pinniped species: implications for the QFASA dietary quantification technique. Mar Ecol Prog Ser 467:263-276

Rosenthal MD (1987) Fatty acid metabolism of isolated mammalian cells. Prog Lipid Res 26:87-124

Rudy MD, Kainz MJ, Graeve M, Colombo SM, Arts MT (2016) Handling and storage procedures have variable effects on fatty acid content in fishes with different lipid quantities. PLOS ONE 11:e0160497

Ryg M, Smith TG, Oritsland NA (1990) Seasonal changes in body mass and body composition of ringed seals (Phoca hispida) on Svalbard. Can J Zool 68:470-475

Sargent JR, Falk-Petersen S (1988) The lipid biochemistry of calanoid copepods. Hydrobiologia 167-168:101-114

Sargent JR, Whittle KJ (1981) Lipids and hydrocarbons in the marine food web. In: Longhurst AR (ed) Analysis of marine ecosystems. Academic Press, London, p 491-533

Scheffer VB (1950) Growth layers on the teeth of Pinnipedia as an indication of age. Science 112:309-311

Søreide JE, Hop H, Carroll ML, Falk-Petersen S, Hegseth EN (2006) Seasonal food web structures and sympagicpelagic coupling in the European Arctic revealed by stable isotopes and a two-source food web model. Prog Oceanogr 71:59-87

Søreide JE, Falk-Petersen S, Hegseth EN, Hop H, Carroll ML, Hobson KA, Blachowiak-Samolyk K (2008) Seasonal feeding strategies of Calanus in the high-Arctic Svalbard region. Deep Sea Res II 55:2225-2244

Søreide JE, Leu E, Berge J, Graeve M, Falk-Petersen S (2010) Timing of blooms, algal food quality and Calanus glacialis reproduction and growth in a changing Arctic. Glob Change Biol 26:3154-3163

Stenson GB, Haug T, Hammill MO (2020) Harp seals: monitors of change in differing ecosystems. Front Mar Sci 7: 569258

Stock BC, Semmens BX (2016a) MixSIAR GUI user manual. Version 3.1. https://github.com/brianstock/MixSIAR (accessed 1 Dec 2020)

Stock BC, Semmens BX (2016b) Unifying error structures in commonly used biotracer mixing models. Ecology 97: 2562-2569
Stock BC, Jackson AL, Ward EJ, Parnell AC, Phillips DL, Semmens BX (2018) Analyzing mixing systems using a new generation of Bayesian tracer mixing models. PeerJ 6:e5096

* Strandberg U, Käkelä A, Lydersen C, Kovacs KM, GrahlNielsen O, Hyvärinen H, Käkelä R (2008) Stratification, composition, and function of marine mammal blubber: the ecology of fatty acids in marine mammals. Physiol Biochem Zool 81:473-485

* Svensen C, Halvorsen E, Vernet M, Franzè G, Dmoch K, Lavrentyev PJ, Kwasniewski S (2019) Zooplankton communities associated with new and regenerated primary production in the Atlantic inflow North of Svalbard. Front Mar Sci 6:293

* Tamelander T, Renaud PE, Hop H, Carroll ML, Ambrose WG Jr, Hobson KA (2006) Trophic relationships and pelagicbenthic coupling during summer in the Barents Sea Marginal Ice Zone, revealed by stable carbon and nitrogen isotope measurements. Mar Ecol Prog Ser 310:33-46

* Tamelander T, Reigstad M, Hop H, Ratkova T (2009) Ice algal assemblages and vertical export of organic matter from sea ice in the Barents Sea and Nansen Basin (Arctic Ocean). Polar Biol 32:1261-1273

Thiemann GW, Iverson SJ, Stirling I (2007) Variability in the blubber fatty acid composition of ringed seals (Phoca hispida) across the Canadian Arctic. Mar Mamm Sci 23: 241-261

*Thyrring J, Tremblay R, Sejr MK (2017) Importance of ice algae and pelagic phytoplankton as food sources revealed by fatty acid trophic markers in a keystone species (Mytilus trossulus) from the High Arctic. Mar Ecol Prog Ser 572:155-164

* Tinoco J (1982) Dietary requirements and functions of $\alpha$ linolenic acid in animals. Prog Lipid Res 21:1-45

Tollit DJ, Pierce GJ, Hobson KA, Bowen WD, Iverson SJ (2010) Diet. In: Boyd IL, Bowen WD, Iverson SJ (eds) Marine mammal ecology and conservation: a handbook of techniques. Oxford University Press, Oxford, p 191-221

*Tremblay JÉ, Michel C, Hobson KA, Gosselin M, Price NM (2006) Bloom dynamics in early opening waters of the Arctic Ocean. Limnol Oceanogr 51:900-912

Van Leeuwe MA, Tedesco L, Arrigo KR, Assmy P and others (2018) Microalgal community structure and primary production in Arctic and Antarctic sea ice: a synthesis. Elem Sci Anth 6:4

Vihtakari M (2020) ggOceanMaps: plot data on oceanographic maps using 'ggplot2'. R package version 0.5.0. https:// mikkovihtakari.github.io/ggOceanMaps (accessed 1 Dec 2020)

Viso AC, Marty JC (1993) Fatty acids from 28 marine microalgae. Phytochemistry 34:1521-1533

*Wang SW, Budge SM, Gradinger RR, Iken K, Wooller MJ (2014) Fatty acid and stable isotope characteristics of sea ice and pelagic particulate organic matter in the Bering Sea: tools for estimating sea ice algal contribution to Arctic food web production. Oecologia 174:699-712

Wang SW, Springer AM, Budge SM, Horstmann L, Quakenbush LT, Wooller MJ (2016) Carbon sources and trophic relationships of ice seals during recent environmental shifts in the Bering Sea. Ecol Appl 26:830-845

Wassmann P, Carmack E, Bluhm BA, Duarte CM and others (2020) Towards a unifying pan-Arctic perspective: a conceptual modelling toolkit. Prog Oceanogr 189:102455

* Wathne JA, Haug T, Lydersen C (2000) Prey preference and niche overlap of ringed seals Phoca hispida and harp 
seals P. groenlandica in the Barents Sea. Mar Ecol Prog Ser 194:233-239

Weslawski JM, Ryg M, Smith TG, Oritsland NA (1994) Diet of ringed seals (Phoca hispida) in a fjord of west Svalbard. Arctic 47:109-114

Wiedmann I, Ershova E, Bluhm BA, Nöthig EM, Gradinger RR, Kosobokova K, Boetius A (2020) What feeds the benthos in the Arctic basins? Assembling a carbon budget for the deep Arctic Ocean. Front Mar Sci 7:224

Young BG, Ferguson SH (2013) Seasons of the ringed seal: pelagic open-water hyperphagy, benthic feeding over

Editorial responsibility: Keith Hobson,

London, Ontario, Canada

Reviewed by: S. Wang and 3 anonymous referees winter and spring fasting during molt. Wildl Res 40: $52-60$

*Young BG, Loseto LL, Ferguson SH (2010) Diet differences among age classes of Arctic seals: evidence from stable isotope and mercury biomarkers. Polar Biol 33: 153-162

*Yurkowski DJ, Brown TA, Blanchfield PJ, Ferguson SH (2020) Atlantic walrus signal latitudinal differences in the long-term decline of sea ice-derived carbon to benthic fauna in the Canadian Arctic. Proc Biol Sci 287: 20202126

Submitted: December 23, 2020

Accepted: July 14, 2021

Proofs received from author(s): September 13, 2021 